\title{
ANALYSIS OF TIME MANAGEMENT IN ONLINE LEARNING AT DARUZ ZAHRA ISLAMIC BOARDING SCHOOL
}

\author{
Akhmad Syahri \\ Universitas Islam Negeri Mataram, NTB, Indonesia \\ akhmadsyahri@uinmataram.ac.id
}

\begin{abstract}
This study aims to determine the effectiveness of time management in bold learning at Daruz Zahra Islamic Boarding School. Students who live in Islamic boarding schools and participate in formal school activities are based on their knowledge of time. However, are students able to manage the time to study materials at Islamic boarding schools and general studies at school during the Covid-19 pandemic? Researchers used descriptive qualitative research methods with data collection techniques and a semi-structured interview model in the form of a questionnaire distributed to 7 students. The data obtained was then processed by tabulating the answer data, description and analysis, data synthesis, and discussion. The results showed that: 1) continuous learning for Daruz Zahra Islamic Boarding School students was not very effective. This was caused by repeated boredom, so that it reached a saturation point. 2) Less than half of the material that students can absorb, coupled with the ability of teachers and students to use the internet, is still low, 3) Students tend to find it difficult to manage their time between formal learning and studying in Islamic boarding schools. Therefore, courageous learning should ideally be carried out in certain conditions and times that do not allow face-to-face meetings, such as natural disasters, and accompanied by increased professionalism of educators in using technology so that learning is not boring.
\end{abstract}

Keywords: Time Management; Online Learning; Islamic Boarding Schools.

\section{INTRODUCTION}

Islamic boarding schools are places of learning for students (Fathurrochman, 2017). Pesantren comes from the word pe-santri, which means the residence of the santri, or what is known as the pupil. Pondok comes from the Arabic word funduuq, which means lodging or hostel. According to Rizki (Hidayat, 2016), there are at least 2 opinions that can be used as a reference. First, Santri is derived from the Sanskrit word 
"santri," which means "literacy." Second, the word santri comes from the Javanese "Cantrik", which means someone who follows a teacher, wherever he goes or stays, to be able to learn about science from him. Pesantren has similarities with hermitages in several ways, namely the presence of students (cantrik or santri), the presence of teachers (Kiai or receipt), the existence of buildings (pesantren or hermitage), and the existence of teaching and learning activities (Hidayat, 2016),

According to Madjid (Fathurrochman, 2017), states that in terms of historicity, pesantren is not only synonymous with Islamic meaning, but also contains the meaning of Indonesian authenticity (indigenous). In the pesantren tradition, apart from being taught the Koran and studying religious knowledge, students are also taught to practice and be responsible for what they have learned. Pesantren also teaches the values of simplicity, independence, cooperation, solidarity, and sincerity (Muhakamurrohman, 2014). Islamic boarding schools are faced with many challenges, including the modernization of Islamic education. Today it deals with time management that must be balanced.

Humans who are not able to use time well will always be accompanied by failure, loss, and regret, as mentioned in the Qur'an's surah al-Ashr, verses 1-3 (Barri, 2016). Time is one of the central points of life. Someone who wastes time, in essence, is reducing the meaning of his life (Tasmaran, 2001). Therefore, time must be arranged in such a way as to carry out useful actions which are called time management.

Management comes from Latin, namely from the origin of the word manus, which means hand, and is, which means to do. The words are combined to form the verb manager, which means "to manage." The manager is translated into English in the form of the verb to manage, with the noun management and manager for people who carry out management activities and translated into Indonesian to become management or management (Hakim, 2018). According to the Big 
Indonesian Dictionary, management is "the process of effectively using resources to achieve predetermined targets, effectively using resources to achieve goals" (Bahasa, 2008).

Time management is the act and process of planning and implementing conscious control over the amount of time that will be used for certain activities, in particular, to increase effectiveness, efficiency, and productivity (Gea, 2014).

Time management can improve students' academic performance (Susan L, 2015), and is a significant contributing factor to student achievement or success (Raadt, 2009); (Ahmad, 2019). Therefore, teachers must integrate the concepts and applications of time management in the classroom as well as possible (Sayari et al., 2017), through planning, approaching and adjusting to the needs of students (Tonks et al., 2021), which is integrated with the learning environment (Holzweiss et al., 2020), school resources (Goodyear \& Armour, 2021), quality of work programs, and institutional policies (Muller et al., 2020).

The current state of the Covid-19 pandemic has resulted in extraordinary changes, including in the field of education. It's as if all levels of education are being forced to adapt abruptly and dramatically to doing learning from home via online media (Atsani, 2020). Online learning and self-regulation have a significant effect on time management (Batbaatar \& Amin, 2021). In time management, students are required to be balanced in managing and managing time. In addition to having a task in the Koran, students must also be able to balance it with formal academic learning. Santri Daruz Zahra, who managed teaching and learning activities (KBM) during the pandemic, was still in the process of getting used to online learning. Students who are allowed to carry gadgets will be limited in their use, so as not to interfere with the KBM of the Daruz Zahra Islamic Boarding School. 
A well-designed learning management system (Kumi-yeboah \& Kim, 2020), independent learning strategies (Yeh et al., 2019), and Realistic Job Preview can help students' readiness to learn (Liu, 2019), and students' academic success in participating in online learning (Latheef et al., 2021).

The Minister of Education and Culture of the Republic of Indonesia devised a home-based learning scheme with an e-learning learning system, with the learning results being sent online. This is because of the dangers of this virus to children, who are very susceptible to infection (Atsani, 2020). Online learning is not an easy thing, because the pesantren is not ready to provide and permit the use of gadgets by students. The problem with the world of education is that the learning process is not uniform, both in its standards and in the quality of the desired learning outcomes. As a result, one of the most common issues that students face when entering an Islamic boarding school and a formal education is time management. During the pandemic, they must divide their time between formal education and studying as a santri in a boarding school. Santri must follow the routine schedule that has been made by the administrator and approved by the caretaker of the boarding school from waking up in the morning until going back to sleep. Students must also adjust their study schedules to take classes through the online system. Therefore, time is one of the key elements in collaborative learning (Guitert, 2011). So, the author concludes that time management does not only refer to time management but is more likely to use time. Individuals who can manage time will determine the priority of the various tasks at hand, focusing their time and energy on the task first.

\section{METHOD}

The method used in this research is descriptive and qualitative. Data collection techniques use semi-structured interviews using a 
questionnaire. The questionnaire is written in the form of an open answer. 7 respondents filled out the online questionnaire. The data obtained was then processed in several stages, as follows.

1. Data tabulation. The answers given by the respondents are studied first. Then the answers are divided into groups of answers in this study, called answer categories. Categorization of answers is based on the criteria for the similarity of the respondent's answer ideas.

2. Description and Analysis. The data that has been sorted into answer categories is then described and analyzed to find out and explain the meaning based on the respondents' answers.

3. Synthesis of Data with Character Concepts. The data that has been analyzed is then synthesized with the concept of national character, which is oriented towards the results of the analysis of the respondents' answers. It can be said that this synthesis is explained implicitly in the main discussion.

4. Discussion. The last stage is the discussion process of the tabulation, description, analysis, and synthesis of the respondents' answers. The discussion is carried out thoroughly, meaning that it no longer mentions the previous sections. In other words, the discussion is carried out comprehensively.

\section{RESULT AND DISCUSSION}

\section{Assessment and effectiveness of online learning}

Of the 7 students interviewed, 5 students thought online learning was not effective. Because students feel that much of the material delivered through online learning is not understood, especially learning that requires more detailed explanations by the teacher, such as mathematics, physics, chemistry, economics, hadith interpretation, and ushul fiqh (WW. Student A, 05-05-2021, 9:00 a.m.). The use of cellphone facilities is also limited, while the teacher gives assignments and deadlines can be at any 
time so that sometimes students do not understand what assignments have not been done (WW. Student B, 05-05-2021, at 09.30). Sometimes, network problems and quotas are limited. suddenly run out when filling out an online exam. This is the result of research by Abidin et al. (Abidin et al., 2020), which states that the most common obstacle that arises during the implementation of online learning is internet packages that students do not have. In addition, students' understanding is reduced because they continue to rely on Google when there is an exam (WW. Student C, 10-05-2021, 10.00).

Another student stated that online learning at the cottage during the pandemic period was less effective because students could not understand the lesson, and had difficulty socializing with friends (WW. Student E, 18-05-2021, 10:10). Students also feel uncomfortable if they hold their cellphones too often (WW. Student G, 18-05-2021, $10.30 \mathrm{am}$ ). Meanwhile, 2 other students feel that online learning is more effective in the activities of the cottage program, because there is additional time to study the book and the Koran, and can support other positive activities (WW. Students D and F, 10-05-2021, 12.00).

They feel that the application of online learning that they get is only centered on giving assignments. The ratio of giving materials is very small. In addition, access to questions is also not as wide as during faceto-face learning, both by asking teachers and friends. This is the result of Yensy's research (Yensy, 2020), that the distance education system is one solution to overcoming difficulties in face-to-face learning, but the implementation of distance education during the spread of the Covid-19 pandemic caused various problems, one example of which is that online learning makes students fantasize more because the process of explaining the material is not in detail, like in offline learning. Furthermore, the effectiveness of online learning is determined by time management in doing assignments. 


\section{The advantages and disadvantages of online learning}

The experiences felt by students regarding the advantages and disadvantages of online learning are very varied, including:

Advantages:

a. Students do not need to be tired of going to school, are more relaxed and simple, do not have to wear uniforms (WW. Student D, 10-05-2021, 12.00).

b. Students can fill in attendance lists and do assignments anywhere (WW. Student A, 05-05-2021, 12.00).

c. Students can contact parents with their cellphones (WW. Siswa G, 18-052021, $10.30 \mathrm{am})$.

d. Students can build cooperation with friends and can contact their parents (WW. Student C, 10-05-2021, 10.00).

e. Students can work together when there are assignments or exams by looking for references when the subject matter is not understood, can communicate with friends and parents, simplify or expedite the learning system in the field of technology (WW. Student D, 10-05-2021, 12.00).

f. Students felt that in the past, they rarely did assignments because they were too lazy to look for task formulas, but now there is a desire to do assignments and look for their formulas through Google (WW. Student F, 10-05-2021, 12.00).

g. Students feel they can be more relaxed, don't wear uniforms anymore, can only pray during the day, can sleep a lot, have a lot of free time, can do more Islamic boarding school assignments, can call their parents (WW. Student B, 05-05-2021, 09.30).

Deficiency:

a. Students feel wasteful because the quota runs out quickly.

b. Students find it more difficult to understand the material presented by the teacher. 
c. Students feel sad because the pocket money they get is reduced.

d. Students feel that social activities with their friends are hampered (WW. all students, 18-05-2021, at 09.30).

The distance education system is one solution to overcoming difficulties in face-to-face learning (Yensy, 2020). The use of online media or multimedia-based media is one solution to making students able to understand the subject matter well so that the material presented can be absorbed perfectly (Mustakim, 2020). In addition, online learning can improve technology skills (Spencer \& Temple, 2021). Indirectly, teachers must be skilled in the use of technology (Fischer et al., 2021) and students are led to practice using technology so that online learning runs effectively (Means \& Neisler, 2021). So, during this pandemic, the teaching and learning process must be carried out in a network (Satrio et al., 2020). This dramatically altered learning system has had a significant impact on the world of education (Simatupang et al., 2020). This will answer whether the use of technology can replace the role of the teacher or if the teacher will not be replaced by any sophisticated technology.

\section{Solutions to minimize obstacles}

Based on the results of research related to their experiences regarding improvements that should be made when implementing online so that online-based learning can be better. The suggestions that respondents gave were varied, such as:

a. Explanation of learning materials: Students expect teachers to continue to provide explanations of learning materials. Students recommend explaining the material through videos. They feel the material is easy to accept and understand.

b. Following the trend of technological advances: Students hope that teachers can follow the trend of technological advances, namely by utilizing applications/social media that are liked by students, so students feel more enthusiastic, enthusiastic, and not easily bored. Students 
recommend that occasionally learning can be done with IG Live. They feel happy and when conducting a question and answer session, it feels easier (WW. all students, 18-05-2021, 09.30).

This is evident from the results of Aan Widiyono's research (Widiyono, 2020). These interesting and enjoyable learning media will be able to eliminate boredom in the classroom. Student online lectures require variations to eliminate boredom (Widiyono, 2020). In addition to the use of interesting learning media, in online lectures, lecturer creativity is needed in learning to avoid boredom (Hikmat; Hermawan, 2020). This is what students need today. Online learning should not be too long, which can make students lose concentration. This learning process should not take more than one hour.

\section{Impact of online learning on worship and learning}

The results of research related to balancing school assignments and boarding school assignments show various things:

a. Students feel that they do more cottage assignments than at school.

b. Students perceive a large number of assignments piling up, making it difficult to work on them.

c. Consistently arriving late for boarding school assignment duties.

d. Students may become drowsy, which may cause them to take longer to complete activities that will be completed later.

e. Students feel that their time management is not good, so many assignments are neglected (WW. all students, 18-05-2021, at 09.30).

In this case, it demonstrates that students struggle to manage their study time, both for school assignments and for boarding school assignments. Students lack the value of assertiveness. The value of assertiveness must be possessed by students so that they can focus on activities that lead to goals. Activities that are not useful are sometimes not planned so that they spend more time studying. Good time management carried out by students can affect the learning outcomes 
obtained because effective and efficient time management can produce good learning achievements.

\section{How to manage time during a pandemic}

Based on the findings, it shows that how to manage students' time is:

a. Students make study schedules include when it's time to sleep and study and keep the spirit in living it.

b. At night, students prioritize huts, worship, and schoolwork.

c. Students synchronize and divide time between online learning and cottage learning, managing time as well as possible.

d. Dhohir and his mind must be maintained.

e. Time management is considered well, such as when it is time to wash, time to learn because the only one who knows the proportion of our abilities is ourselves (WW. all students, 18-05-2021, 09.30).

How important is study time management for students? A good and appropriate study time is different for each student. This difference is based on busyness, the available time allocation, the learning atmosphere, and the readiness to learn.

\section{CONCLUSION}

Based on the findings and discussion, it can be concluded that continuous online learning for Daruz Zahra Islamic Boarding School students is very ineffective. This is caused by repeated boredom so that it reaches a saturation point. In addition, less than half of the materials that students can absorb, coupled with the ability of teachers and students to use the internet, is still very low. Thus, online learning is considered quite effective when it is only done from time to time, not continuously for 1 semester. The students tend to find it difficult to manage the time between formal learning and studying at the pesantren.

In the future, online learning should only be carried out under certain conditions that do not allow face-to-face learning, such as a natural 
disaster, and accompanied by an increase in teacher professionalism in the use of technology so that learning is not boring.

\section{REFERENCES}

Abidin, Z., Arizona, K., Barat, N. T., Studi, P., \& Fisika, T. (2020). PEMBELAJARAN ONLINE BERBASIS PROYEK SALAH SATU SOLUSI KEGIATAN BELAJAR MENGAJAR DI TENGAH PANDEMI COVID-19. Jurnal Ilmiah Profesi Pendidikan, 5(1), 64-70. https://doi.org/10.29303/jipp.v5i1.111

Ahmad, S. (2019). Path Relationship of Time Management and Academic Achievement of Students in Distance Learning Institutions. Pakistan Journal of Distance \& Online Learning, V(II), 191-208.

Atsani, L. G. M. Z. (2020). TRANSFORMASI MEDIA PEMBELAJARAN PADA MASA PANDEMI COVID-19. Al-Hikmah: Jurnal Studi Islam, 1(1), 82-93.

Bahasa, T. P. K. P. (2008). Kamus Bahasa Indonesia. Pusat Bahasa Departemen Pendidikan Nasional.

Barri, F. (2016). MANAJEMEN WAKTU SANTRI DI DAYAH TAHFIDZ ULUMUL QUR ' AN PAGAR AIR BANDA ACEH. Jurnal Ilmiah DIDAKTIKA, 17(1), 138-155.

Batbaatar, N., \& Amin, G. (2021). STUDENTS ' TIME MANAGEMENT DURING ONLINE CLASS. The International Conference of Universitas Pekalongan, 189-194.

Fathurrochman, I. (2017). Implementasi Manajemen Kurikulum Dalam Upaya Meningkatkan Mutu Santri Pondok Pesantren Hidayatullah / Panti Asuhan Anak Soleh Curup. TADBIR : Jurnal Studi Manajemen Pendidikan, 1(01).

Fischer, F., Sailer, M., \& Murb, J. (2021). Digital learning in schools : What does it take beyond digital technology? Teaching and Teacher Education, 103, 1-13. https://doi.org/10.1016/j.tate.2021.103346

Gea, A. A. (2014). TIME MANAGEMENT: MENGGUNAKAN WAKTU SECARA EFEKTIF DAN EFISIEN. HUMANIORA, 5(45), 777-785. 
Goodyear, V. A., \& Armour, K. M. (2021). Young People's health-related learning through social media: What do teachers need to know? Teaching and Teacher $\quad$ Education, 103340. https://doi.org/10.1016/j.tate.2021.103340

Guitert, M. (2011). TIME MANAGEMENT IN VIRTUAL Time management in virtual collaborative learning: the case of the Universitat Oberta de. ELC Research Paper Series, 2, 5-16. http://elcrps.uoc.edu

Hakim, A. (2018). Manajemen Kurikulum Terpadu di Pondok Pesantren Modern Daarul Huda Banjar. Jurnal Penelitian Pendidikan Islam, 6(1).

Hidayat, M. (2016). Model Komunikasi Kyai dengan Santri di Pesantren. Jurnal Komunikasi ASPIKOM, 2(6), 385-395.

Hikmat; Hermawan, E. (2020). Efektivitas Pembalajaran Daring Selama Masa Pandemi Covid-19 : Sebuah Survey Online. Karya Tulis Ilmiah (KTI) Masa Work From Home (WFH) Covid-19 UIN Sunan Gunung Djati Bandung, 17.

Holzweiss, P. C., Walker, D. W., Chisum, R., \& Sosebee, T. (2020). Crisis Planning for Online Students: Lessons Learned from a Major Disruption. Online Learning Journal, 24(2), 22-37. https://doi.org/https://doi.org/10.24059/olj.v24i2.2135

Kumi-yeboah, A., \& Kim, Y. (2020). Exploring the Use of Digital Technologies from the Perspective of Diverse Learners in Online Learning Environments. Online Learning Journal -, 24(4), 42-63. https://doi.org/https://doi.org/10.24059/olj.v24i4.2323

Latheef, Z. I., Robinson, R., \& Smith, S. (2021). Realistic Job Preview as an Alternative Tool to Improve Student Readiness for Online Learning. Online Learning Journal, 25(2), 208-232. https://doi.org/https://doi.org/10.24059/olj.v25i2.2216

Liu, J. C. (2019). Evaluating Online Learning Orientation Design With a Readiness Scale. Online Learning Journal, 23(4), 42-61. https://doi.org/10.24059/olj.v23i4.2078

Means, B., \& Neisler, J. (2021). Teaching and Learning in the Time of COVID : 
The Student Perspective. Online Learning Journal, 25(1), 8-17. https://doi.org/https://doi.org/10.24059/olj.v25i1.2496

Muhakamurrohman, A. (2014). Pesantren: Santri, Kiai dan Tradisi. Ibda': Jurnal Kebudayaan Islam, 12(2), 109-118.

Muller, K., Scalzo, K. A., Pickett, A. M., Dugan, L., Dubuc, L., Simiele, D., Mccabe, R., \& Pelz, W. (2020). Ensuring Online Learning Quality: Perspectives from the State University of New York. Online Learning Journal, $24(2)$ 254-268.

https://doi.org/https://doi.org/10.24059/olj.v24i2.2004

Mustakim. (2020). The Effectiveness Of E-Learning Using Online Media During The Covid-19 Pandemic in Matematics. Al Asma: Journal of Islamic Education, 2(1), 1-12.

Raadt, M. \& S. D. (2009). A simple time-management tool for students online learning activities. Proceedings Ascilite Auckland 2009: Concise Paper: De Raadt and Dekeyser, 194-199.

Satrio, Y. D., Handayani, S., Abbas, M. H. I., \& Kustiandi, J. (2020). Studi Komparasi Metode Pembelajaran dalam Meningkatkan Literasi Keuangan di Masa Pandemi Covid-19. Jurnal Pendidikan Ekonomi Undiksha, 12(1), 29-35.

Sayari, K., Jalagat, R., \& Dalluay, V. (2017). Assessing the Relationship of Time Management and Academic Performance of the Business Students in AlZahra College for Women. European Business \& Management, 3(1), 1-8. https://doi.org/10.11648/j.ebm.20170301.11

Simatupang, N. I., Rejeki, S., Sitohang, I., Patricia, A., \& Simatupang, I. M. (2020). Efektivitas Pelaksanaan Pengajaran Online Pada Masa Pandemi Covid-19 dengan Metode Survei Sederhana. Jurnal Dinamika Pendidikan, 13(2), 197-203. https://doi.org/DOI 10.33541/jdp.v13i2.1754

Spencer, D., \& Temple, T. (2021). Examining Students ' Online Course Perceptions and Comparing Student Performance Outcomes in Online and Face-to-Face Classrooms. Online Learning Journal, 25(2), 233-261. https://doi.org/https://doi.org/10.24059/olj.v25i2.2227 
Susan L, C. \& B. (2015). Time Management Skills and Student Performance in Online Courses. 122nd ASEE Annual Conference \& Exposition, 1, 14-17.

Tasmaran, T. (2001). Kecerdasan Ruhaniah. Gema Insani Press.

Tonks, D., Kimmons, R., \& Mason, S. L. (2021). Motivations Among Special Education Students and their Parents for Switching to an Online School : Survey Responses and Emergent Themes. Online Learning Journal -, 25(2), 171-189. https://doi.org/https://doi.org/10.24059/olj.v25i2.2141

Widiyono, A. (2020). Efektifitas Perkuliahan Daring (Online) pada Mahasiswa PGSD di Saat Pandemi Covid 19. Jurnal Pendidikan, 8(2), 169-177.

Yeh, Y., Kwok, O., Chien, H., \& Sweany, N. W. (2019). How College Students ' Achievement Goal Orientations Predict Their Expected Online Learning Outcome: The Mediation Roles of Self-Regulated Learning Strategies and Supportive Online Learning Behaviors. Online Learning Journal, 23(4), 23 41. https://doi.org/10.24059/olj.v23i4.2076

Yensy, N. A. (2020). Efektifitas Pembelajaran Statistika Matematika melalui Media Whatsapp Group Ditinjau dari Hasil Belajar Mahasiswa (Masa Pandemik Covid 19). Jurnal Pendidikan Matematika Raflesia, 05(02), 6574. https://ejournal.unib.ac.id/index.php/jpmr 